\title{
Daptomisinin VRE ve MRSA Suşlarına In Vitro Etkinliği*
}

\section{In Vitro Activity of Daptomycin Against VRE and MRSA Strains}

\author{
Gülseren AKTAŞ ${ }^{1}$, Şengül DERBENTLi' \\ ${ }^{1}$ İstanbul Üniversitesi İstanbul Tıp Fakültesi, Tıbbi Mikrobiyoloji Anabilim Dalı, İstanbul. \\ ${ }^{1}$ Istanbul University Faculty of Istanbul Medicine, Department of Medical Microbiology, Istanbul, Turkey.
}

* Bu çalışmanın bir bölümü, İstanbul Üniversitesi Bilimsel Araştırma Projeleri Birimi tarafından desteklenmiş ve 7. Balkan Mikrobiyoloji Kongresi (Microbiologia Balkanica 2011; October 25-29, 2011, Belgrade, Serbia)'nde poster olarak sunulmuştur.

Geliş Tarihi (Received): 03.07.2013 • Kabul Ediliş Tarihi (Accepted): 04.11.2013

\section{ÖZET}

Çoğul antibiyotik dirençli gram-pozitif bakterilerin etken olduğu enfeksiyonlar, tüm dünyada giderek artmaktadır. Metisiline dirençli Staphylococcus aureus (MRSA) ve vankomisine dirençli enterokoklar (VRE), hastane enfeksiyonlarına neden olan en önemli bakterilerdir. Tedavide yaygın vankomisin kullanımı, duyarıı̆ı̆ı azalmış veya dirençli suşların giderek artmasına yol açmaktadır. Yeni bir lipopeptid antibiyotik olan daptomisin, MRSA ve enterokok türleri dahil, gram-pozitif bakterilerin çoğuna karşı hızlı bir bakterisidal etkinliğe sahiptir. Bu çalışmada, hastanemizin çeşitli kliniklerinde yatan hastaların klinik örneklerinden izole edilen VRE ve MRSA suşlarının in vitro daptomisin duyarlılı̆̆ııı araştıııması amaçlanmıştır. Çalışmaya 118 VRE ve 111 MRSA olmak üzere toplam 229 suş alınmış olup, tümü rektal sürüntü örneklerinden izole edilen VRE suşlarının ikisi aynı zamanda linezolide de dirençlidir (MiK değerleri $8 \mu \mathrm{g} /$ $\mathrm{ml}$ ve $12 \mu \mathrm{g} / \mathrm{ml}$ ). Suşların tanımlanması konvansiyonel yöntemler ile yapılmış; daptomisin duyarıı̆ı̆ının araştııılmasında CLSI önerilerine uygun olarak, sıvı mikrodilüsyon yöntemi uygulanmıştır. Elde edilen MiK değerleri, daptomisin için CLSI tarafından önerilen duyarlıık sınır değerlerine göre yorumlanmıştır. VRE izolatlarında daptomisinin MiK $_{50}$ ve Mik ${ }_{90}$ değerleri sırasıyla $1 \mu \mathrm{g} / \mathrm{ml}$ ve $2 \mu \mathrm{g} / \mathrm{ml}$ olarak bulunmuş, MiK aralığı ise $0.125-2 \mu \mathrm{g} / \mathrm{ml}$ olarak belirlenmiştir. MRSA izolatlarında daptomisin MiK ${ }_{50}$ ve $\mathrm{MiK}_{90}$ değerleri sırasıyla $0.12 \mu \mathrm{g} / \mathrm{ml}$ ve $0.5 \mu \mathrm{g} / \mathrm{ml}$, MiK aralığı $\leq 0.032-1 \mu \mathrm{g} / \mathrm{ml}$ olarak saptanmışır. Bu verilere göre daptomisin, linezolide dirençli iki suş da dahil olmak üzere, tüm VRE ve MRSA suşlarına (\%100) etkili bulunmuştur. Sonuç olarak daptomisin, VRE ve MRSA enfeksiyonlarının sınırlı sayıdaki tedavi seçeneklerine bir alternatif tedavi olanağı sunmasına karşın, azalmış duyarlılık gösteren suşlar ve tedavi sırasında duyarlıık azalması göz önüne alınarak, özellikle uzun süreli daptomisin tedavileri esnasında izole edilen VRE ve MRSA suşlarında MiK değerlerinin dikkatle izlenmesi, tedavi başarısızlığını önlemede yararlı olacaktır.

Anahtar sözcükler: Daptomisin; duyarlılık; vankomisine dirençli enterokok; metisiline dirençli Staphylococcus aureus; mikrodilüsyon yöntemi. 


\section{ABSTRACT}

Infections with multidrug-resistant (MDR) gram-positive bacteria are gradually increasing in the world. Methicillin-resistant Staphylococcus aureus (MRSA) and vancomycin-resistant enterococci (VRE) are among the leading pathogens isolated from nosocomial infections. The increased use of vancomycin in the treatment has led to the development of isolates with reduced susceptibility and resistance. Daptomycin is a novel lipopeptide antibiotic which has a rapid bactericidal activity against infections caused by gram-positive bacteria including MRSA and VRE. The aim of this study was to evaluate the in vitro activity of daptomycin against VRE and MRSA strains isolated from clinical samples of hospitalized patients. A total of 229 isolates of which 118 were VRE and 111 were MRSA have been included in the study. All of the VRE strains were isolated from rectal swab samples and two of them were also resistant to linezolid with the MIC values of $8 \mu \mathrm{g} / \mathrm{ml}$ and $12 \mu \mathrm{g} / \mathrm{ml}$. Bacterial identification was performed by conventional methods and susceptibility testing of daptomycin was performed by using the broth microdilution method as recommended by CLSI. The MIC values were interpreted according to CLSI susceptibility criteria for daptomycin. Daptomycin $\mathrm{MIC}_{50}$ and $\mathrm{MIC}_{90}$ values for VRE were found as $1 \mu \mathrm{g} /$ $\mathrm{ml}$ and $2 \mu \mathrm{g} / \mathrm{ml}$, respectively, with a MIC range of $0.125-2 \mu \mathrm{g} / \mathrm{ml}$. Daptomycin $\mathrm{MIC}_{50}$ and $\mathrm{MIC}_{90}$ values for MRSA were determined as $0.12 \mu \mathrm{g} / \mathrm{ml}$ and $0.5 \mu \mathrm{g} / \mathrm{ml}$, respectively, and the overall distribution of MIC values ranged between $\leq 0.032-1 \mu \mathrm{g} / \mathrm{ml}$. All VRE including two linezolid-resistant strains and all MRSA strains (100\%) were found susceptible to daptomycin. It was concluded that daptomycin is one of the few alternative agents for the treatment of infections caused by VRE and MRSA, nevertheless it was suggested that daptomycin MICs should better be monitored to prevent treatment failure due to the presence of non-susceptible strains and possible emergence of strains with decreased susceptibility during long-term therapy.

Key words: Daptomycin; susceptibility; vancomycin-resistant enterococci; methicillin-resistant Staphylococcus aureus; microdilution method.

\section{GiRiş}

Gram-pozitif kokların etken olduğu enfeksiyonların tedavisi çoğul antimikrobiyal dirençli suşların yaygınlaşması nedeniyle her geçen gün zorlaşmaktadır. Son yıllarda yapılan sürveyans çalışmaları, metisiline dirençli Staphylococcus aureus (MRSA) ve vankomisine dirençli enterokok (VRE) suşlarının etken olduğu enfeksiyonların tüm dünyada giderek arttığını ve hastanelerde en sık izole edilen dirençli bakteriler olduğunu göstermektedir ${ }^{1}$. Glikopeptid antibiyotiklerin kullanıma girmesi önemli bir tedavi olanağı sunmuşsa da, bu antibiyotiklere dirençli bakterilerle gelişen enfeksiyonların oranı giderek artmaktadır. Özellikle vankomisine duyarlılığı azalmış S.aureus (VISA) ve vankomisine dirençli S.aureus (VRSA) suşlarının ortaya çıkışı, ciddi MRSA enfeksiyonlarının tedavisindeki seçenekleri kısıtlamıştır ${ }^{2,3}$.

Daptomisin, lipopeptid yapısında yeni bir antibiyotik olup, VRE, MRSA ve VISA gibi tedavisi güç enfeksiyonlara neden olan bakteriler de dahil, aerop ve anaerop grampozitif bakterilere, konsantrasyona bağımlı olarak hızı bakterisit etki göstermektedir. Etki mekanizması diğer antimikrobiyal ilaçlardan farklı olan daptomisin, oligorimerizasyon ile hücre zarı bütünlüğünü bozarak etkinlik gösterir. Depolarizasyon sonucu sitoplazma zarı işlevini kaybeder ve hücre hızla ölür. Daptomisin hücre lizisine neden olmadığından, 
hücre duvarı ve hücre içi komponentlerinin salınımı ve buna bağlı komplikasyon gelişme riski oluşturmamaktadır ${ }^{4}$. Bu çalışmada, klinik örneklerden izole edilen VRE ve MRSA suşlarına karşı daptomisinin etkinliğinin in vitro olarak belirlenmesi amaçlanmıştır.

\section{GEREÇ ve YÖNTEM}

Çalışmaya, hastanemizin çeşitli kliniklerinde yatan hastalardan alınan klinik örneklerin rutin incelenmesi sırasında izole edilen 118 VRE ve 111 MRSA suşu alındı.

VRE suşları hastaların rektal sürüntü örneklerinden izole edildi. Örnekler, enterokoklar için seçici bir besiyeri olan azid-dekstroz buyyonuna (Merck, Almanya) ekilerek $35^{\circ} \mathrm{C}$ 'de bir gece inkübe edildi. Daha sonra $6 \mu \mathrm{g} / \mathrm{ml}$ vankomisin içeren triptik-soy agar (TSA; Oxoid, Ingiltere) besiyerine ekilerek aynı koşullarda 24-48 saat inkübasyona bırakıldı. Vankomisinli TSA besiyerinde üreyen bakteriler, konvansiyonel yöntemlerle cins düzeyinde tanımland $\imath^{5,6}$. Gram-pozitif, katalaz negatif, $\% 6.5 \mathrm{NaCl}$ içeren besiyerinde üreme, \%40 safra varlığında eskülini hidrolize etme ve pirolidonil arilamidaz (PYR; BD, ABD) testi pozitif suşlar Enterococcus spp. olarak kabul edildi ve disk difüzyon yöntemi ile vankomisin (30 $\mu$; Oxoid, İngiltere) direnci araştırıldı. Çalışmaya alınan 118 VRE suşundan ikisi aynı zamanda linezolide de dirençli suşlar olup, E-test yöntemiyle linezolid Mik değerleri 8 ve $12 \mu \mathrm{g} / \mathrm{ml}$ olarak belirlendi ${ }^{7}$.

S.aureus suşlarının izolasyon ve tanımlanması da konvansiyonel yöntemlerle yapıldı́ . Gram-pozitif, küme oluşturan; katalaz, DNaz ve plazma koagülaz testleri pozitif olan ve $30 \mu g^{\prime}$ Iık sefoksitin diski ile yapılan duyarlılık deneylerinde dirençli bulunan suşlar MRSA olarak tanımlandı.

Daptomisinin (Novartis Pharma AG, İsviçre) VRE ve MRSA suşları için MiK değerleri "Clinical and Laboratory Standards Institute (CLSI)" önerileri doğrultusunda mikrodilüsyon yöntemi ile belirlendi. Deneylerde, $\% 12.5 \mu \mathrm{g} / \mathrm{ml}$ magnezyum ve $50 \mu \mathrm{g} / \mathrm{ml} \mathrm{kal}$ siyum ilave edilmiş Mueller-Hinton buyyonu (BBL ${ }^{\mathrm{TM}}$, Becton Dickinson, $\mathrm{ABD}$ ), çözücü, sulandırıcı ve suşların inokülasyonunda besiyeri olarak kullanıldı ${ }^{8}$. Her iki bakteri cinsi için antibiyotiğin test edilen konsantrasyon aralığı 0.032-16 $\mu \mathrm{g} / \mathrm{ml}$ idi. Plaklar bir gece $35^{\circ} \mathrm{C}^{\prime}$ de inkübasyondan sonra gözle görülen üremenin durduğu en düşük antibiyotik konsantrasyonu, MiK değeri olarak saptandı ve sonuçlar CLSI'nın belirlediği direnç sınır değerlerine göre (VRE: $\leq 4 \mu \mathrm{g} / \mathrm{ml}$; MRSA: $\leq 1 \mu \mathrm{g} / \mathrm{ml}$ ) değerlendirildi. Kalite kontrol suşları olarak S.aureus ATCC 29213 ve E.faecalis ATCC 29212 kullanıldı?.

\section{BULGULAR}

Çalışmamızda, VRE ve MRSA izolatlarına karşı saptanan daptomisinin in vitro duyarlılık sonuçları Tablo I'de sunulmuştur. Linezolide dirençli iki suş da dahil, incelenen 118 VRE ve 111 MRSA suşlarının tümü daptomisine duyarlı bulunmuştur. VRE ve MRSA suşlarında daptomisin MiK değerlerinin dağılımı Tablo II'de gösterilmiştir. 
Tablo I. VRE ve MRSA Suşlarına Karşı Daptomisinin In Vitro Duyarııık Sonuçları

\begin{tabular}{lcccc}
\hline & \multicolumn{4}{c}{ MiK $(\mu \mathrm{g} / \mathrm{ml})$} \\
\cline { 2 - 4 } Suşlar (Sayı) & MiK $_{50}$ & MiK $_{90}$ & MiK aralığı & Duyarlılık (\%) \\
\hline VRE (118) & 1 & 2 & $0.125-2$ & 100 \\
MRSA (111) & 0.12 & 0.5 & $\leq 0.032-1$ & 100 \\
\hline
\end{tabular}

Tablo II. VRE ve MRSA Suşlarında Daptomisin Mik Değerlerinin Dă̆ı̆ımı

\begin{tabular}{lccccccc}
\hline & \multicolumn{7}{c}{ MiK $(\boldsymbol{\mu g} / \mathbf{m l})(\%)$} \\
\cline { 2 - 8 } Suşlar (Sayı) & $\leq \mathbf{0 . 0 3 2}$ & $\mathbf{0 . 0 6}$ & $\mathbf{0 . 1 2}$ & $\mathbf{0 . 2 5}$ & $\mathbf{0 . 5}$ & $\mathbf{1}$ & $\mathbf{2}$ \\
\hline VRE (118) & 0 & 0 & $1(0.8)$ & $1(0.8)$ & $43(36.4)$ & $53(45)$ & $20(17)$ \\
MRSA (111) & $10(9)$ & $13(11.7)$ & $43(38.7)$ & $29(26)$ & $15(13.5)$ & $1(0.9)$ & 0 \\
\hline \multicolumn{10}{c}{} & & & & & \\
\hline
\end{tabular}

\section{TARTIŞMA}

Daptomisin, siklik bir lipopeptid antibiyotiktir ve bakteri sitoplazma zarının depolarizasyonuna neden olarak hızlı bakterisidal etki gösterir ${ }^{4}$. Stafilokoklarda görülen daptomisin direncinin başlıca nedenleri; lisilfosfatidil-gliserin sentetaz, histidin kinaz ve RNA polimeraz alt ünitlerini kodlayan sırasıyla $m p r F$, yycG, rpoB ve $r p o C$ genlerindeki mutasyonlardır ${ }^{10}$. Bunun yanı sıra vankomisin ile karşılaşmış olmanın, daptomisin direnci gelişimine zemin oluşturabileceğini gösteren veriler vardır ${ }^{11}$. Enterokoklarda daptomisin direncine ilişkin kesin bilgi bulunmamakla birlikte, stafilokoklardaki direnç mekanizmalarına benzer yollarla geliştiği düşünülmektedir ${ }^{12}$.

Ülkemizin de dahil olduğu 13 Avrupa ülkesinden 34 merkezin katıldığı bir çalışmada, 2003-2009 yılları arasında izole edilen \%27.2'si metisiline dirençli 18.352 S.aureus ve \%9.4'ü vankomisine dirençli 7.241 enterokok suşunun in vitro daptomisin duyarlılığı araştırılmış ve suşların \%100'ü daptomisine duyarlı bulunmuştur ${ }^{13}$. Aynı suşların Mik $_{50}$ ve Mik $_{90}$ değerleri ise sırasıyla MRSA suşları için 0.25 ve 0.5 , VRE için ise 2 ve $2 \mu \mathrm{g} / \mathrm{ml}$ olarak bildirilmiştir ${ }^{13}$. Bizim çalışmamızda bu değerler sırasıyla 0.12 ve 0.5 ile 1 ve $2 \mu \mathrm{g} /$ $\mathrm{ml}$ olarak belirlenmiştir.

Amerika Birleşik Devletleri (ABD)'nde 2003 yılı sonlarında S.aureus'un etken olduğu komplike deri ve yumuşak doku enfeksiyonlarının, 2006 yılında da bakteriyemilerin tedavisinde daptomisin kullanılmaya başlanmıştır. Daptomisin direncinin araştırıldığı bir sürveyans çalışmasında, 2007-2008 yıllarında ABD'deki tıp merkezlerinden toplanan 4.514 MRSA ve vankomisine dirençli 78 E.faecalis, 640 E.faecium suşunun daptomisin MiK $_{90}$ değerleri sırasıyla 0.5, 1 ve $2 \mu \mathrm{g} / \mathrm{ml}$, duyarlılık oranları da aynı sıra ile \%99.8, \%100 ve \%99.7 olarak bildirilmiştir ${ }^{14}$. Aynı çalışmada, 2002-2003 (daptomisin onayı öncesi) ve 2007-2008 yıllarında izole edilen S.aureus ve enterokok suşları için belirlenen daptomisin Mik değerlerinin birbirine çok yakın olduğu da vurgulanmıştır ${ }^{14}$. 
Bazı çalışmalarda daptomisine duyarlı olmayan (MiK> $4 \mu \mathrm{g} / \mathrm{ml}$ ) çok az sayıda enterokok suşuna rastlanmasına karşın ${ }^{14}$, vankomisin, linezolid ve kinupristin/dalfopristin ile kıyaslandığında, en yüksek duyarlılık oranlarının veya en düşük Mik değerlerinin daptomisin ile elde edildiği bildirilmektedir ${ }^{14,15}$. Bazı çalışmalarda ise, VRE ve S.aureus'un neden olduğu enfeksiyonların daptomisin ile tedavisi sırasında yükselmiş MiK değerlerinin saptandığı ve bu durumun tedavi başarısızlıklarına yol açtığı ifade edilmektedir ${ }^{16}$. Ülkemizde yapılan bir çalışmada, sekiz farklı şehirden dokuz hastanenin yoğun bakım ünitelerinde yatan hastalardan izole edilen 260 MRSA suşunda E-test yöntemi ile daptomisin aktivitesi araştırılmıştır ${ }^{17}$. Suşların MiK $_{50}$ ve MiK $_{90}$ değerleri sırasıyla 0.094 ve 0.19 $\mu \mathrm{g} / \mathrm{ml}$ olarak saptanmış, MRSA izolatlarından birinin $(1 / 260, \% 0.4)$ ise daptomisine duyarlı olmadığı bildirilmiştir ${ }^{17}$. Ülkemizde yapılan diğer çalışmalarda E-test ile MRSA suşlarının Mik değerleri $\leq 1 \mu \mathrm{g} / \mathrm{ml}$ olarak belirlenmiştir ${ }^{18-20}$. Çalışmamızın verileri ve diğer araştırmaların ${ }^{18-20}$ sonuçları, klinik örneklerden izole edilen gram-pozitif patojenler arasında, Cesur ve arkadaşlarının ${ }^{17}$ rapor ettiği bir suş hariç, ülkemizde daptomisine duyarlı olmayan suşa rastlanmadığını göstermektedir. Bu bulgular VRE ve MRSA dahil çoğul antibiyotik dirençli gram-pozitif bakterilerin etken olduğu enfeksiyonların tedavisinde daptomisinin güvenilir bir alternatif oluşturabileceği fikrini vermektedir. Daptomisinin ülkemizde 2010 yılında kullanılmaya başlanan yeni bir antibiyotik olması ${ }^{18}$ ve tedavi sırasında duyarlı olmayan suşların ortaya çıkabileceği ${ }^{16}$ dikkate alınarak, daptomisin Mik değerleri izlenmelidir.

\section{TEŞEKKÜR}

Çalışmada kullanılan daptomisini sağlayan Novartis Pharma AG firmasına teşekkür ederiz.

\section{KAYNAKLAR}

1. European Centre for Disease Prevention and Control. European Antimicrobial Resistance Surveillance Network (EARS-Net). Available at: http://www.rivm.nl/earss/database/

2. Hiramatsu K, Hanaki H, Ino T, Yabuta K, Oguri T, Tenover FC. Methicillin-resistant Staphylococcus aureus clinical strain with reduced vancomycin susceptibility. J Antimicrob Chemother 1997; 40(1): 135-6.

3. Centers for Disease Control and Prevention. Staphylococcus aureus resistant to vancomycin-United States, 2002. MMWR Morb Mortal Wkly Rep 2002; 51(26): 565-7.

4. Cottagnoud P. Daptomycin: a new treatment for insidious infections due to gram-positive pathogens. Swiss Med Wkly 2008; 138(7-8): 93-9.

5. Teixeira LM, Facklam RR. Enterococcus, pp: 422-33. In: Murray PR, Baron EJ, Jorgensen JH, Pfaller MA, Yolken RH (eds), Manual of Clinical Microbiology. 2003, $8^{\text {th }}$ ed. ASM press, Washington DC.

6. Winn W Jr, Allen S, Janda W, et al (eds). Koneman's Color Atlas and Textbook of Diagnostic Microbiology, $2006,6^{\text {th }}$ ed. Lippincott Williams\&Wilkins, Philadelphia.

7. Aktaş G, Bozdoğan B, Derbentli S. Linezolid ve dalbavansinin vankomisine dirençli enterokok suşlarına karşı in vitro aktivitesi. Mikrobiyol Bul 2012; 46(3): 359-65.

8. Clinical and Laboratory Standards Institute. Methods for dilution antimicrobial susceptibility tests for bacteria that grow aerobically. Approved Standard, Document M7-A7, 2006. CLSI, Wayne, PA. 
9. Clinical and Laboratory Standards Institute. Performance standards for antimicrobial susceptibility testing. $18^{\text {th }}$ Informational Supplement M100-S18, 2008. CLSI, Wayne, PA.

10. Friedman L, Alder JD, Silverman JA. Genetic changes that correlate with reduced susceptibility to daptomycin in Staphylococcus aureus. Antimicrob Agents Chemother 2006; 50(6): 2137-45.

11. Hirschwerk D, Ginocchio CC, Bythrow M, Condon S. Diminished susceptibility to daptomycin accompanied by clinical failure in a patient with methicillin-resistant Staphylococcus aureus bacteremia. Infect Control Hosp Epidemiol 2006; 27(3): 315-7.

12. Arias $C A$, Murray BE. Emergence and management of drug-resistant enterococcal infections. Expert Rev Ant Infect Ther 2008; 6(5): 637-55.

13. Sader HS, Farrell DJ, Jones RN. Antimicrobial activity of daptomycin tested against gram-positive strains collected in European hospitals: results from 7 years of resistance surveillance (2003-2009). J Chemother 2011; 23(4): 200-6.

14. Sader HS, Jones RN. Antimicrobial susceptibility of gram-positive bacteria isolated from US medical centers: results of the Daptomycin Surveillance Program (2007-2008). Diagn Microbiol Infect Dis 2009; 65(2): 158-62.

15. Canton R, Ruiz-Garbajosa P, Chaves RL, Johnson AP. A potential role for daptomycin in enterococcal infections: what is the evidence? J Antimicrob Chemother 2010; 65(6): 1126-36.

16. Kelesidis T, Humphries R, Uslan DZ, Pegues D. De novo daptomycin-non-susceptible enterococcal infections. Emerg Infect Dis 2012; 18(4): 674-6.

17. Cesur S, Irmak H, Simşek H ve ark. Türkiye'de yedi ildeki hastanelerin yoğun bakım ünitelerinden izole edilen MRSA suşlarında VISA-VRSA araştırılması ve antibiyotik duyarlılık durumlarının saptanması. Mikrobiyol Bul 2012; 46(3): 352-8.

18. Yılmaz Bozkurt G, Kutlu H, Arslan A, Memikoğlu O. Yeni bir antibakteriyel ajan: daptomisin. Ankara Üniv Tıp Fak Mecm 2010; 63(3): 85-8.

19. Afşar I, Güngör S, Şener AG, Demirci M. Daptomisinin kan kültürlerinden izole edilen metisiline dirençli Staphylococcus aureus suşlarına in vitro etkinliği. Mikrobiyol Bul 2011; 45(4): 755-7.

20. Çelikbilek N, Özdem B, Gürelik FC, Güvenman S, Güner HR, Açıkgöz ZC. Metisiline dirençli Staphylococcus aureus izolatlarının vankomisin, teikoplanin, linezolid ve daptomisine in vitro duyarlılıkları. Mikrobiyol Bul $2011 ; 45(3): 512-8$. 